\title{
Erratum for Olson and Tharp, How did the Passaic River, a Superfund site near Newark, New Jersey, become an Agent Orange dioxin TCDD hotspot?
}

Volume 75(2), p. 33A: Lines 1-6 in the Author Information box should read as follows: "Kenneth R. Olson is a US Army Vietnam Era veteran and professor emeritus of soil science in the Department of Natural Resources, College of Agriculture Consumer and Environmental Sciences, University of Illinois, Urbana, Illinois."

\section{Reference}

K.R. Olson and M. Tharp. 2020. How did the Passaic River, a Superfund site near Newark, New Jersey, become an Agent Orange dioxin TCDD hotspot? Journal of Soil and Water Conservation 75(2):33A-37A, DOI: https://doi.org/10.2489/jswc.75.2.33A. 